\title{
Pola Pertumbuhan dan Pemanenan Biomassa dalam Fotobioreaktor Mikroalga untuk Penangkapan Karbon
}

\author{
Growth Pattern and Biomass Harvesting in Microalgal Photobioreactor \\ for Carbon Sequestration
}

\author{
Joko Prayitno \\ Pusat Teknologi Lingkungan - BPPT \\ Gedung Geostech 820, Puspiptek Serpong 15314, Indonesia \\ Email: joko.prayitno@bppt.go.id \\ Diterima : 15 Oktober 2015; Diperiksa : 30 Oktober 2015; Revisi : 16 Desember 2015; Disetujui :07 Desember 2015
}

\begin{abstract}
Microalgal photobioreactor is a technology depend on photosynthesis processes to fix and convert $\mathrm{CO}_{2}$ gas into biomass. Critical factors influencing microalgal growth, $\mathrm{CO}_{2}$ fixation and biomass production in photobioreactor include microalgal species, supply of $\mathrm{CO}_{2}$, nutritional status, light, temperature, $\mathrm{pH}$ and mixing of culture. In addition to those factors, growth characteristics and harvesting are also important to obtain high carbon fixation rate and biomass productivity for large scale application. There is still little information available until recently on the growth characteristics and biomass productivities of photobioreactor microalgae using different harvesting strategies, i.e. semi-continuous and continuous. The aims of this paper were to discuss about microalgae growth pattern in photobioreactor in relation to the harvesting strategies using batch, semi-continuous or continuous system; and to determine the most appropriate system for implementation of carbon-fixation photobioreactor in Indonesia. Based on advantages and disadvantages of those three systems, semi-continuous system appeared to be the most appropriate choice.
\end{abstract}

Keywords: Biomass, photobioreactor, microalgae, harvesting, carbon fixation

\begin{abstract}
ABSTRAK
Teknologi fotobioreaktor mikroalga untuk penangkapan karbon merupakan teknologi yang mengandalkan proses fotosintesis untuk memfiksasi gas $\mathrm{CO}_{2}$ dan mengkonversinya menjadi biomassa. Faktor utama yang mempengaruhi proses pertumbuhan, fiksasi karbon dan produksi biomassa adalah jenis mikroalga, gas $\mathrm{CO}_{2}$, nutrisi, cahaya, suhu, $\mathrm{pH}$ dan pengadukan. Untuk aplikasi teknologi ini dalam skala besar, selain faktor-faktor tersebut di atas, karakteristik pertumbuhan mikroalga tertentu dan pemanenannya perlu diketahui untuk mendapatkan hasil yang maksimum. Hingga saat ini masih sedikit informasi yang diperoleh tentang karakteristik pertumbuhan dan produksi biomassa dari mikroalga dalam fotobioreaktor yang dipanen dengan sistem semi-kontinu dan sistem kontinu. Tujuan dari tulisan ini adalah membahas tentang pola pertumbuhan sel-sel mikroalga dalam fotobioreaktor yang berkaitan dengan strategi pemanenan sistem batch, semi-kontinu dan kontinu, dan untuk menentukan sistem yang lebih cocok diterapkan di Indonesia. Berdasarkan kelebihan dan kekurangan dari masing-masing sistem, pemanenan sistem semi-kontinu menjadi pilihan utama untuk aplikasi fotobioreaktor mikroalga penangkap karbon di Indonesia.
\end{abstract}

Kata Kunci: Biomassa, fotobioreaktor, mikroalga, pemanenan, penangkapan karbon

\section{PENDAHULUAN}

Pemanasan global yang disebabkan karena emisi gas rumah kaca terutama gas $\mathrm{CO}_{2}$ menjadi isu lingkungan penting dewasa ini. Fiksasi $\mathrm{CO}_{2}$ berbasis mikroalga merupakan teknologi yang potensial dikembangkan untuk mengurangi emisi $\mathrm{CO}_{2}$ terutama dari cerobong industri. Teknologi ini mengandalkan proses fotosintesis oleh sel-sel mikroalga yang menggunakan gas $\mathrm{CO}_{2}$ sebagai substrat untuk pembentukan senyawa karbohidrat yang akan dikonversi menjadi biomassa. Biomassa mikroalga terdiri dari sekitar $50 \%$ karbon, yang semuanya berasal dari fiksasi
$\mathrm{CO}_{2}{ }^{(1,2)}$, meskipun tidak semua $\mathrm{CO}_{2}$ yang difiksasi dikonversi menjadi biomassa karena sebagian merupakan gas volatil dan senyawa organik yang diekskresikan keluar sel ${ }^{(2)}$. Secara teoritis, mikroalga dapat memfiksasi sekitar 513 ton $\mathrm{CO}_{2}$ yang menghasilkan 280 ton biomassa per ha dalam setahun ${ }^{(3)}$, atau untuk menghasilkan $1 \mathrm{~kg}$ biomassa diperlukan fiksasi karbon sebanyak 1,83 kg.

Beberapa keuntungan yang ditawarkan teknologi penangkap karbon berbasis mikroalga adalah laju pertumbuhan dan fiksasi yang tinggi dan lingkungan pertumbuhan yang dapat 
dikontrol. Selain itu biomassa yang dihasilkan dapat dimanfaatkan untuk produk bernilai tinggi seperti bahan baku bioplastik, farmasi, kosmetik, detergen dan pangan fungsional ${ }^{(4,5)}$, produk pakan $^{(6)}$ dan bahan baku energi ${ }^{(7)}$.

Teknologi fiksasi $\mathrm{CO}_{2}$ berbasis mikroalga yang telah banyak dikembangkan diantaranya adalah teknologi fotobioreaktor. Dalam teknologi ini, kapasitas serapan $\mathrm{CO}_{2}$ dan produksi biomassa adalah dua target utama untuk ditingkatkan. Keduanya sangat bergantung pada optimasi kondisi proses pertumbuhan mikroalga seperti jenis mikroalga yang digunakan, suplai $\mathrm{CO}_{2}$, cahaya, nutrisi, suhu kultur, $\mathrm{pH}$ kultur, pengadukan dan konsentrasi gas $\mathrm{O}_{2}$ dalam kultur $^{(8)}$. Disain fotobioreaktor juga turut menentukan optimasi proses penumbuhan mikroalga $^{(9)}$.

Dalam 20 tahun terakhir, pengembangan teknologi fotobioreaktor mikroalga penangkap karbon telah mengalami peningkatan baik dalam skala bench maupun skala pilot. Pengembangan teknologi ini di Indonesia masih dalam tahap awal meskipun sebagai negara tropis Indonesia memiliki potensi besar untuk pengembangan teknologi ini karena memiliki kelimpahan sinar matahari sepanjang tahun dan biodiversitas mikroalga yang tinggi. Karena itu pengembangan teknologi ini perlu dipacu sehingga dapat diperoleh manfaat dari aplikasi teknologi ini.

Meskipun informasi dan pengetahuan tentang disain fotobioreaktor dan faktor-faktor yang dapat meningkatkan kapasitas serapan $\mathrm{CO}_{2}$ dan produksi biomassa semakin bertambah, namun masih banyak hal-hal yang belum diketahui dengan detil, terutama keterkaitan antar faktor yang berpengaruh terhadap pembentukan biomassa ${ }^{(8,10)}$. Sebagai contoh, jenis mikroalga yang berbeda memiliki respon pertumbuhan yang berbeda terhadap intensitas cahaya, konsentrasi $\mathrm{CO}_{2}$ dan suhu tertentu, sedangkan intensitas cahaya mempengaruhi suhu kultur yang kemudian mempengaruhi serapan $\mathrm{CO}_{2}{ }^{(11)}$. Selain itu, kinerja fotobioreaktor skala laboratorium belum tentu sama dengan kinerja pada skala yang lebih besar. Dalam beberapa kasus, kegagalan dalam implementasi teknologi ini pada skala besar disebabkan karena faktor kurangnya data dan informasi sebagai basis untuk aplikasi skala besar. Oleh karena itu, simulasi proses penangkapan karbon dan produksi biomassa dalam fotobioreaktor mikroalga merupakan langkah penting yang perlu dilakukan.

Hal lainnya yang perlu mendapat perhatian dalam proses produksi biomassa mikroalga dan penangkap karbon menggunakan fotobioreaktor adalah pola pertumbuhan dan pemanenan. Biomassa yang dihasilkan harus dipanen secara berkala agar kinerja fotobioreaktor penangkap karbon tetap optimal tanpa mempengaruhi pola pertumbuhan dalam jangka waktu lama. Interval waktu panen dan jumlah yang dipanen menjadi hal yang penting. Selain itu kepadatan sel yang perlu dipertahankan agar proses produksi dapat berjalan kontinu juga perlu diketahui.

Tujuan dari tulisan ini adalah melakukan kajian tentang pola pertumbuhan mikroalga dalam fotobioreaktor dan pola pemanenan yang diperlukan agar kapasitas penangkapan karbon dan produksi biomassa dapat dicapai secara maksimum. Dalam makalah ini, topik yang terlebih dahulu dibahas adalah mengenai pertumbuhan mikroalga dalam fotobioreaktor sistem batch, pengaruh $\mathrm{CO}_{2}$, nutrisi dan cahaya terhadap pola pertumbuhan mikroalga, kemudian pola pertumbuhan sistem semi-kontinu, dan terakhir pola pertumbuhan sistem kontinu. Pada akhir makalah beberapa kelebihan dan kekurangan dari ketiga sistem pemanenan tersebut dibahas secara singkat untuk menentukan sistem fotobioreaktor penangkap karbon yang lebih cocok diterapkan di Indonesia.

\section{BAHAN DAN METODE}

Makalah ini disusun berdasarkan pengalaman dan kajian literatur. Bahan diambil dari literatur kajian (review) dan hasil riset yang dilakukan oleh berbagai universitas dan lembaga penelitian di luar negeri, baik dalam skala labolatorium maupun skala banch, dengan menggunakan sistem batch, semi kontinyu dan kontinyu.

\section{HASIL DAN PEMBAHASAN}

\subsection{Pertumbuhan Mikroalga dalam Fotobio- reaktor Sistem Batch}

Mikroalga merupakan pelaku pada proses penangkapan $\mathrm{CO}_{2}$ dalam fotobioreaktor, karena itu pemahaman tentang pertumbuhan mikroalga merupakan hal penting dalam pengoperasian fotobioreaktor. Mikroalga yang tumbuh pesat selama pengoperasian fotobioreaktor merupakan cerminan kinerja fotobioreaktor yang baik.

Pola pertumbuhan mikroalga dalam fotobioreaktor batch sama seperti pertumbuhan organisme lain pada umumnya, yaitu berbentuk kurva sigmoid yang terdiri dari empat fase yaitu fase linier (lag phase), eksponensial, stasioner, dan kematian. Kurva pertumbuhan mikroalga tersebut dapat dilihat pada Gambar 1.

Pada fase pertumbuhan linier, sel-sel mikroalga yang dimasukkan ke dalam fotobioreaktor mulai beradaptasi dengan kondisi lingkungan di dalam fotobioreaktor. Secara fisiologis, sel-sel tersebut mempersiapkan diri untuk melakukan pembelahan sel pada usia tertentu, dengan cara 
memproduksi enzim-enzim dan senyawa metabolisme lainnya yang diperlukan untuk pembelahan sel. Dalam fase ini, sel-sel yang membelah masih sedikit sehingga jumlah sel tidak banyak mengalami peningkatan. Karena itu fase ini disebut juga lag phase.

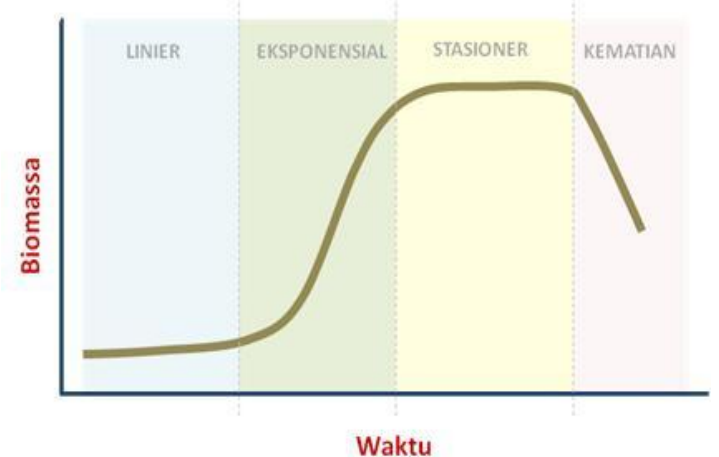

Gambar 1. Fase pertumbuhan mikroalga dalam fotobioreaktor (dimodifikasi dari de Morais dan Costa, 2007 ${ }^{(13)}$ )

Setelah fase pertumbuhan linier, sel-sel memasuki fase pertumbuhan eksponensial, dimana sel-sel membelah diri dengan cepat dan enzim-enzim dan senyawa-senyawa metabolit yang dibutuhkan untuk pembelahan sel sudah tersedia. Fase pertumbuhan dengan tingkat serapan $\mathrm{CO}_{2}$ dan laju pembentukan biomassa yang tinggi terjadi pada fase eksponensial. Pada fase ini juga terjadi serapan nutrisi dari media secara cepat sehingga nutrisi dalam fotobioreaktor berkurang. Ketersediaan nutrisi yang menurun secara cepat dalam fotobioreaktor menjadi salah satu faktor penyebab pertumbuhan mikroalga memasuki fase stasioner dimana laju pertambahan sel seimbang dengan laju kematian sel. Secara umum dalam sistem batch, sel-sel mikroalga memasuki fase stasioner pada hari ke 5-10. Bila faktor-faktor pendukung pertumbuhan semakin terbatas, maka sel-sel mikroalga memasuki fase kematian yang ditandai dengan kematian sel-sel dalam jumlah besar, sedangkan pembelahan sel hampir tidak terjadi.

Pertumbuhan mikroalga dalam fotobio-reaktor dinyatakan dengan pertambahan biomassa per volume tertentu per satuan waktu (hari), atau biasa dikenal dengan istilah produktifitas biomassa. Produktifitas biomassa dihitung pada saat mikroalga berada dalam fase eksponensial berdasarkan rumus 1 berikut ${ }^{(12)}$ :

$$
P=\frac{X_{1}-X_{0}}{t_{1}-t_{0}}
$$

dimana : $\boldsymbol{P}=$ produktifitas biomassa $(\mathrm{g} / \mathrm{L} / \mathrm{hari})$;

$\boldsymbol{X}_{\boldsymbol{1}}=$ produksi biomassa pada hari ke- $\mathrm{t}_{1}(\mathrm{~g} / \mathrm{L})$;

$\boldsymbol{X}_{\boldsymbol{0}}=$ produksi biomassa pada hari ke- $\mathrm{t}_{0}(\mathrm{~g} / \mathrm{L})$;

$\boldsymbol{t}_{1}-\boldsymbol{t}_{\boldsymbol{0}}=$ selang waktu pada fase eksponensial (hari)
Pertumbuhan mikroalga dapat juga dinyatakan dengan pertambahan jumlah, densitas atau populasi sel (jumlah sel/mL). Pola pertumbuhan mikroalga berdasarkan jumlah sel tidak selalu sama dengan pola pertumbuhan berdasarkan biomassa. Berdasarkan pertambahan jumlah sel pada rentang hari tertentu pada saat fase eksponensial, maka waktu regenerasi sel mikroalga khususnya mikroalga sel tunggal seperti Chlorella dapat dihitung berdasarkan rumus 2 dan $3^{(13)}$ :

$$
\begin{aligned}
& \boldsymbol{K}=\frac{\operatorname{Ln}\left(N_{t}-N_{o}\right)}{t_{1}-t_{0}} \\
& \mathbf{G t}=\frac{\operatorname{Ln} 2}{24 \times K}
\end{aligned}
$$

dimana: $\boldsymbol{K}=$ Laju pertumbuhan spesifik; $\boldsymbol{G} \boldsymbol{t}=$ waktu generasi (jam); $\boldsymbol{N}_{\boldsymbol{t}}=$ populasi sel pada hari ke-t fase eksponensial $(\mathrm{sel} / \mathrm{mL}) ; \boldsymbol{N}_{0}=$ populasi sel pada hari ke-0 fase eksponensial (sel/mL); $\boldsymbol{t}_{\boldsymbol{1}}$ $\boldsymbol{t}_{0}=$ selang waktu pada fase eksponensial (hari)

Seperti yang telah disebutkan di atas, pola pertumbuhan mikroalga dalam fotobioreaktor batch dipengaruhi oleh jenis mikroalga, populasi sel awal dalam media kultur, nutrisi dan faktor lingkungan lainnya. Mengingat pengaruh jenis mikroalga sudah dibahas dibeberapa literatur, maka dalam ulasan ini yang dibahas adalah pengaruh kepadatan sel awal kultur, nutrisi dan faktor lingkungan lainnya terhadap pola pertumbuhan mikroalga.

\subsubsection{Kepadatan Sel di Awal Kultur}

Secara teoritis, produksi biomassa mikroalga ataupun fiksasi karbon meningkat bila kepadatan sel di awal inokulasi meningkat. Hal ini didukung oleh hasil penelitian Chiu et al. yang menunjukkan bahwa kepadatan awal sel yang tinggi $\left(8 \times 10^{6} \mathrm{sel} / \mathrm{mL}\right)$ menghasilkan biomassa yang lebih besar yaitu $1.44 \mathrm{~g} / \mathrm{L}$ dibandingkan dengan kepadatan awal sel yang rendah $\left(8 \times 10^{5}\right.$ $\mathrm{sel} / \mathrm{mL}$ ) yang menghasilkan biomassa sebesar $1.21 \mathrm{~g} / \mathrm{L}^{(14)}$. Selain itu, kepadatan sel awal yang lebih tinggi dapat memperpendek fase diam (lag phase) dan membuat fase eksponensial meningkat secara tajam ${ }^{(14)}$. Kepadatan awal yang tinggi dapat meningkatkan persaingan antar sel untuk mendapatkan nutrisi dan cahaya, karena itu kebutuhan nutrisi dan cahaya hendaknya diberikan dalam jumlah yang cukup selama periode pertumbuhan.

\subsubsection{Faktor yang Mempengaruhi Pola Pertumbuhan Mikroalga}

Tujuan utama pengembangan fotobioreaktor mikroalga penangkap karbon adalah efisiensi fiksasi karbon dan produksi biomassa setinggi mungkin. Pola pertumbuhan yang diinginkan dalam fotobioreaktor batch adalah waktu lag 
phase yang sesingkatnya dan fase eksponensial yang cepat dan meningkat tajam. Oleh karena itu pengukuran dan monitoring laju pertumbuhan mikroalga dalam fotobioreaktor perlu untuk melihat efisiensi penangkapan karbon.

Laju pertumbuhan spesifik dan produktifitas biomassa mikroalga dalam fotobioreaktor batch sangat dipengaruhi oleh jenis mikroalga, kondisi nutrisi dan lingkungan fotobioreaktor. Keseluruhan faktor tersebut akan menentukan waktu yang dibutuhkan oleh kultur mikroalga hingga mencapai akhir fase eksponensial. Bila nutrisi dan lingkungan berada dalam kondisi suboptimum maka fase eksponensial akan berlangsung singkat, bahkan seringkali fase ini tidak tercapai (dengan kata lain pertumbuhan bersifat linier). Bila nutrisi dan lingkungan tetap dijaga dalam kondisi optimum maka secara teoritis fase eksponensial akan berlangsung terus. Namun hal tersebut sulit tercapai dalam sistem batch karena peningkatan jumlah sel dan biomassa menyebabkan terjadi peningkatan viskositas media, penetrasi cahaya yang semakin berkurang terutama di bagian dalam kultur akibat penutupan oleh sel-sel di sebelah luar, dan penurunan kelarutan $\mathrm{CO}_{2}$.

Faktor-faktor yang mempengaruhi produktifitas biomassa dibahas secara singkat berikut ini yaitu $\mathrm{CO}_{2}$, nutrisi terutama $\mathrm{N}$ dan $\mathrm{P}$, dan cahaya.

\section{Suplai $\mathrm{CO}_{2}$}

$\mathrm{CO}_{2}$ memiliki peranan yang vital dalam proses pembentukan biomassa mikroalga dalam fotobioreaktor. Pemberian $\mathrm{CO}_{2}$ meningkatkan produksi biomassa dan sekaligus meningkatkan efisiensi penangkapan karbon. Sebagian besar mikroalga memiliki respon positif bila diberikan $\mathrm{CO}_{2}$ dalam konsentrasi yang rendah yaitu 1$12 \%{ }^{(12)(15) 16)}$. Namun konsentrasi $\mathrm{CO}_{2}$ sebesar $10 \%$ dapat memiliki efek yang negatif bagi sebagian jenis mikroalga ${ }^{(12,14)}$. Efek tersebut selain menyebabkan produksi biomassa rendah, juga menyebabkan pola pertumbuhan menjadi linier ${ }^{(14)}$. Secara umum, peningkatan konsentrasi $\mathrm{CO}_{2}$ optimal yang dianjurkan untuk sebagian besar species mikroalga berada dalam kisaran 2$10 \%{ }^{(17)}$. Meskipun demikian beberapa peneliti menggunakan gas $\mathrm{CO}_{2}$ murni $(100 \%)$ sebagai sumber $\mathrm{CO}_{2}{ }^{(18,19)}$. Sumber $\mathrm{CO}_{2}$ dapat berasal dari udara ambien, emisi cerobong dan tabung gas. Untuk aplikasi penangkapan karbon sumber gas $\mathrm{CO}_{2}$ yang ideal adalah dari emisi cerobong industri. Emisi gas buang industri memiliki kandungan $\mathrm{CO}_{2}$ yang berkisar antara $5-10 \%{ }^{(20)}$. Produksi biomassa dari beberapa species mikroalga yang diberi $\mathrm{CO}_{2}$ pada konsentrasi yang berbeda dapat dilihat pada Tabel 1.

Tabel 1. Produksi biomassa beberapa species mikroalga pada beberapa level $\mathrm{CO}_{2}$

\begin{tabular}{l|l|l|l|l|l|c|c}
\hline species & $\begin{array}{c}\text { Vol } \\
\text { kerja } \\
(\mathrm{L})\end{array}$ & $\begin{array}{l}\mathrm{CO}_{2} \\
(\%)\end{array}$ & $\begin{array}{l}\boldsymbol{K} \\
\text { /hari) }\end{array}$ & $\begin{array}{l}\boldsymbol{P}_{\max } \\
(\mathrm{g} / \mathrm{L} / \mathrm{hari})\end{array}$ & $\begin{array}{l}\boldsymbol{X}_{\max } \\
(\mathrm{g} / \mathrm{L})\end{array}$ & $\begin{array}{c}\text { Puncak produksi } \\
\text { (hari ke-) }\end{array}$ & Referensi \\
\hline Chlorella vulgaris & 8 & 5 & 0,29 & 0,31 & 1,94 & 7 & $(2)$ \\
\hline Botryococcus braunii & 8 & 5 & 0,24 & 0,61 & 3,11 & 9 & $(2)$ \\
\hline Spirulina platensis & 8 & 5 & 0,22 & 0,73 & 2,18 & 9 & $(2)$ \\
\hline Dunaliella tertiolecta & 8 & 5 & 0,21 & 0,42 & 2,15 & 11 & $(2)$ \\
\hline Spirulina sp & 1,8 & 0,03 & 0,33 & 0,04 & 0,82 & 21 & $(13)$ \\
\hline Spirulina sp & 1,8 & 6 & 0,44 & 0,20 & 3,40 & 21 & $(13)$ \\
\hline Scenedesmus obliquus & 1,8 & 0 & 0,15 & 0,04 & 0,31 & 21 & $(13)$ \\
\hline Scenedesmus obliquus & 1,8 & 6 & 0,22 & 0,10 & 1,56 & 21 & $(13)$ \\
\hline Nannochloropsis oculata & 0,8 & 0,03 & 0,19 & $\mathrm{NA}^{*}$ & 0,27 & $6-8$ & $(14)$ \\
\hline Nannochloropsis oculata & 0,8 & 2 & 0,57 & $\mathrm{NA}^{*}$ & 1,28 & $6-8$ & $(14)$ \\
\hline *NA data tidak tersedia
\end{tabular}

${ }^{\star} \mathrm{NA}=$ data tidak tersedia

\section{Nitrogen dan P}

Nitrogen dan fosfor adalah dua unsur yang paling dibutuhkan untuk pertumbuhan mikroalga. Dalam fotobioreaktor, mikroalga mendapatkan kedua unsur tersebut dari media kultur dalam bentuk nitrat atau amonium. Sudah lama diketahui bahwa pemberian nitrogen dan fosfor pada konsentrasi tertentu meningkatkan pertumbuhan mikroalga dan fiksasi $\mathrm{CO}_{2}$. Beberapa media tumbuh yang khusus diformulasikan untuk pertumbuhan mikroalga mengandung nitrogen dan fosfor dalam bentuk nitrat dan fosfat masingmasing sekitar 75-100 mg/L dan 5-18 mg/L. Hasil penelitian Jin et al. menunjukkan bahwa pemberian nitrat pada konsentrasi $15-20 \mathrm{ppm}$ selain menaikkan kepadatan sel juga memperpanjang waktu fase eksponensial lebih dari 3 hari ${ }^{(21)}$. Kebutuhan nutrisi nitrogen dan fosfor dalam fotobioreaktor dapat diduga dari laju serapannya dalam media kultur. Laju serapan nitrogen dan fosfor berdasarkan pembentukan biomassa Chlorella vulgaris dari hasil penelitian Sydney et al. masing-masing sebesar $49 \mathrm{mg} / \mathrm{g}$ dan $314 \mathrm{mg} / \mathrm{g}$ biomassa ${ }^{(2)}$. Laju serapan nitrogen dan fosfor tersebut berbeda tergantung dari spesies mikroalga. 


\section{Cahaya}

Cahaya adalah komponen utama yang dibutuhkan mikroalga untuk pembentukan biomassa dan proses fiksasi karbon. Disain fotobioreaktor dibuat untuk meningkatkan efisiensi serapan cahaya oleh mikroalga yang tergantung pada rasio luas permukaan fotobioreaktor dan volume kultur. Seperti halnya $\mathrm{CO}_{2}$ dan nutrisi, mikroalga memerlukan cahaya dengan intensitas tertentu. Produksi biomassa terus meningkat sejalan dengan peningkatan intensitas cahaya hingga mencapai titik jenuh sekitar 420 $\mu \mathrm{mol} / \mathrm{m}^{2} /$ detik, dengan produksi biomassa maksimum sebesar $840.56 \mathrm{mg} / \mathrm{L} /$ hari dan serapan karbon $1435.90 \mathrm{mg} / \mathrm{L} /$ hari $^{(22)}$. Peningkatan intensitas cahaya tersebut menyebabkan fase eksponensial menjadi semakin tajam ${ }^{(23)(24)(25)}$. Intensitas cahaya yang terlalu tinggi menyebabkan proses fotosintesis terhenti karena adanya mekanisme jenuh cahaya. Kelebihan cahaya tersebut dirubah menjadi panas sehingga suhu kultur naik.

\subsection{Pertumbuhan Mikroalga dalam Fotobio- reaktor Sistem Semi-Kontinu}

Seperti yang sudah disebutkan di atas, fase pertumbuhan dengan tingkat serapan $\mathrm{CO}_{2}$ tertinggi terjadi pada fase eksponensial. Karena itu mikroalga dalam fotobioreaktor perlu dijaga agar tetap berada dalam fase eksponensial supaya : (1) kapasitas serapan $\mathrm{CO}_{2}$ dan laju pembentukan biomassa tetap tinggi selama pengoperasian berlangsung, dan (2) fotobio-reaktor dapat beroperasi secara kontinu dalam waktu lama. Pengoperasian fotobioreaktor skala besar dalam jangka waktu lama akan mengurangi biaya pemeliharaan dan persiapan unit fotobioreaktor untuk pengoperasian selanjutnya.

Pertumbuhan mikroalga dalam fotobio-reaktor perlu dipantau agar dapat ditentukan waktu pemanenan sehingga tidak terjadi kelebihan populasi di dalam unit fotobioreaktor yang akan menghambat efisiensi serapan $\mathrm{CO}_{2}$. Pada unit fotobioreaktor penangkap karbon yang beroperasi dalam jangka waktu lama, pemanenan dapat dilakukan secara berkala (semi-kontinu). Secara umum, pola pertumbuh-an mikroalga dalam fotobioreaktor yang dipanen secara berkala dapat dilihat pada Gambar 2.

Pada saat kultur mikroalga mencapai fase akhir eksponensial dengan produktifitas biomassa maksimum $\left(P_{\max }\right)$ maka kultur dipanen sebagian, kemudian media kultur yang berisi nutrisi ditambahkan ke dalam sistem dengan jumlah yang sama. Kepadatan sel menjadi turun karena terjadi pengenceran setelah ditambahkan media baru. Setelah mikroalga ditumbuhkan dalam jangka waktu tertentu, maka biomassa meningkat kembali dan mencapai $X_{\max }$ Demikian seterusnya mikroalga dipanen dalam periode tertentu.

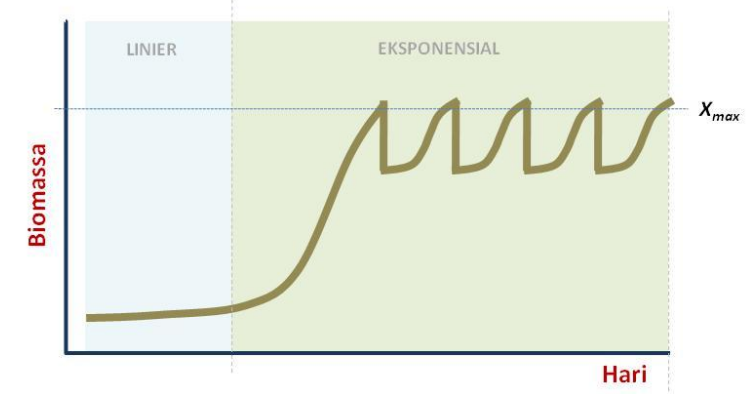

Gambar 2. Pola pertumbuhan mikroalga dalam fotobioreaktor sistem semi-kontinu (dimodifikasi dari Chiu et al. ${ }^{(27)}$ ).

Informasi yang perlu diketahui pada waktu pemanenan sistem pengoperasian semi-kontinu ini adalah rasio yang dipanen dan periode (selang waktu) panen. Informasi dari literatur tentang panen sistem semi-kontinu tersebut tidak banyak tersedia hingga saat ini. Rasio panen yang digunakan berkisar antara $20 \%-33 \%^{(25)}$ hingga $50 \%{ }^{(23)}$. Berdasarkan percobaan yang dilakukan oleh Chae et al. diketahui bahwa periode panen mikroalga Euglena gracilis yang semakin lama dari 3 hari menjadi 5 hari menyebabkan kepadatan sel meningkat dari $2 \times 10^{6} \mathrm{sel} / \mathrm{mL}$ menjadi $3 \times 10^{6}$ $\mathrm{sel} / \mathrm{mL}$ pada akhir percobaan ${ }^{(26)}$. Demikian pula produksi biomassa naik dari $0.2 \mathrm{~g} / \mathrm{L}$ menjadi 0.6 $\mathrm{g} / \mathrm{L}$. Kultur mikroalga tersebut diberi suplai $\mathrm{CO}_{2}$ $11 \%$. Hasil tersebut menunjukkan bahwa semakin lama interval panen dalam sistem pemanenan semi-kontinu, maka sel-sel memiliki waktu yang semakin banyak untuk tumbuh sehingga lebih banyak $\mathrm{CO}_{2}$ yang difiksasi. Hasil yang berbeda diperoleh pada percobaan Chiu et al. dimana produksi biomassa yang stabil dan tetap tinggi $(0.74-0.92 \mathrm{~g} / \mathrm{L})$ dapat diperoleh pada interval waktu panen yang lebih singkat yaitu 1 hari menggunakan mikroalga Nanochloropsis oculata yang diberi $2-15 \% \mathrm{CO}_{2}{ }^{(27)}$. Hasil tersebut diduga karena kepadatan sel awal yang digunakan cukup tinggi yaitu $0.4 \mathrm{~g} / \mathrm{L}$ dan jenis mikroalga yang digunakan berbeda.

Rasio panen dan selang waktu panen berkaitan erat satu sama lain. Untuk mendapatkan produksi biomassa yang sama maka rasio panen yang tinggi menyebabkan selang waktu panen menjadi lebih panjang, karena sel-sel mikroalga membutuhkan waktu lebih lama untuk tumbuh hingga mencapai biomassa sebelum panen.

\subsection{Pertumbuhan Mikroalga dalam Fotobio- reaktor Sistem Operasi Kontinu}

Untuk fotobioreaktor yang dioperasikan dalam skala besar menggunakan jenis mikroalga tertentu, pemanenan dapat dilakukan secara kontinu. 
Dalam hal ini pemanenan harus diatur secara otomatis untuk menyelaraskannya dengan faktor input (terutama nutrisi) dan faktor lingkungan (suhu, $\mathrm{pH}$ dan sirkulasi medium) sehingga diperoleh kondisi pengoperasian yang stabil dan kontinu (steady state). Dalam hal ini, laju aliran (flow rate) dari media yang ditambah-kan ke dalam sistem dan kultur yang dipanen menjadi isu penting. Isu penting lainnya adalah waktu tinggal (retention time) dari media yang diberikan sehingga tetap berada dalam konsentrasi optimal untuk pertumbuhan. Secara teoritis, pola pertumbuhan mikroalga dalam fotobioreaktor penangkap karbon dapat dilihat seperti pada Gambar 3.

Pada tahap awal, sel-sel mikroalga berada dalam tahap pertumbuhan lag phase (linier). Bila faktor input dan kondisi lingkungan tidak menjadi pembatas, maka mikroalga selanjutnya memasuki fase pertumbuhan cepat (eksponen-sial) hingga mencapai produktifitas biomassa maksimum $\left(X_{\text {max }}\right)$. Pada saat tersebut maka kultur mikroalga dipanen dengan laju aliran tertentu secara kontinu. Pada saat yang bersamaan media kultur ditambahkan dengan jumlah yang sama dengan yang dipanen. Laju aliran media yang masuk dan keluar dari sistem fotobioreaktor diatur sedemikian dengan waktu tinggal tertentu sehingga produksi biomassa stabil dalam kondisi maksimum $\left(X_{\max }\right)$.

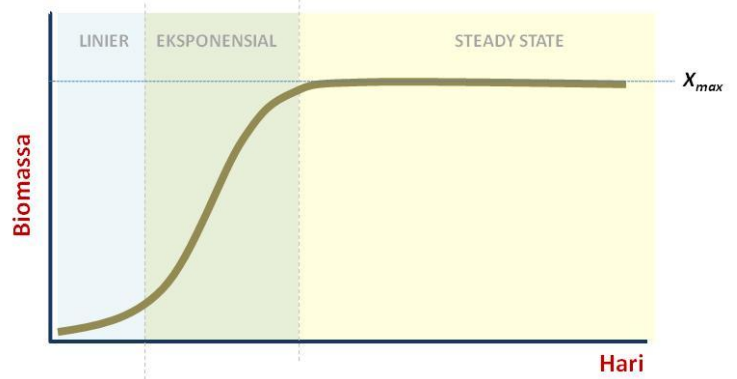

Gambar 3. Pola pertumbuhan mikroalga dalam fotobioreaktor sistem kontinu (dimodifikasi dari Chae et al., $2006^{(26)}$ )

Berdasarkan hasil percobaan Chae et al., mikroalga $E$. gracilis yang dipanen dari fotobioreaktor tipe flat panel dengan kapasitas 100 $\mathrm{L}$ sebesar $20-33 \%$ dengan waktu tinggal 4 hari menghasilkan kepadatan sel yang sama dengan 5 hari yaitu sebesar $3.3 \times 10^{6} \mathrm{sel} / \mathrm{mL}$ dan produksi biomassa sebesar $0.71 \mathrm{~g} / \mathrm{L}^{(26)}$. Chae et al. ${ }^{(26)}$ menyimpulkan bahwa produksi sel dari fotobioreaktor yang dipanen secara kontinu sama dengan yang dipanen secara semi-kontinu dengan waktu tinggal yang sama. Selanjutnya, pada fotobioreaktor dengan kapasitas yang lebih besar (1000 L), waktu tinggal 8 hari menghasilkan biomassa yang lebih besar yaitu $0,91 \mathrm{~g} / \mathrm{L}$ dibandingkan dengan waktu tinggal 3 hari dengan produksi biomassa sebesar $0,51 \mathrm{~g} / \mathrm{L}^{(26)}$.
Berdasarkan uraian di atas, secara teknis pemanenan sistem semi-kontinu menghasilkan produksi biomassa yang sama dengan sistem kontinu pada kapasitas fotobioreaktor dan jenis mikroalga yang sama. Namun kedua sistem tersebut menghasilkan produksi biomassa yang lebih besar dibandingkan dengan sistem batch, karena waktu yang dibutuhkan untuk satu siklus produksi pada sistem batch lebih lama. Hal ini disebabkan karena sistem batch perlu persiapan unit fotobioreaktor untuk periode kultur selanjutnya, seperti pencucian, sterilisasi dan persiapan inokulum. Selain itu waktu panen pada sistem batch menjadi lebih lama karena terdapat lag phase di setiap periode kultur.

Secara umum, pemilihan sistem panen batch, semi-kontinu dan kontinu tergantung dari ketersediaan sumberdaya dan fasilitas yang tersedia. Selain itu, pemanfaatan biomassa untuk tujuan tertentu juga akan menentukan sistem pemanenan yang digunakan. Masing-masing sistem memiliki kelebihan dan kekurangan (Tabel. 2). Kendala utama aplikasi sistem kontinu dalam skala besar di Indonesia adalah faktor cuaca yang dapat mempengaruhi intensitas cahaya dan suhu.

\section{KESIMPULAN}

Pemahaman tentang pola pertumbuhan mikroalga dalam fotobioreaktor penangkap karbon diperlukan untuk kesinambungan produksi biomassa dan efisiensi fiksasi karbon. Faktorfaktor yang mempengaruhi pertumbuhan mikroalga seperti cahaya, nutrisi, $\mathrm{CO}_{2}$ dan faktor lingkungan lainnya (suhu, $\mathrm{pH}$, pengadukan) perlu dipertahankan dalam kondisi optimal agar panen dengan sistem semi-kontinu maupun kontinu dapat menghasilkan biomassa yang maksimum secara berkelanjutan. Untuk aplikasi fotobioreaktor penangkap karbon skala besar yang mengandalkan cahaya dari matahari di daerah tropis seperti Indonesia, intensitas cahaya matahari sangat bergantung pada kondisi cuaca harian yang sulit untuk dikontrol. Kondisi mendung dan hujan tentunya akan menurunkan intensitas cahaya sehingga dalam sistem pemanenan kontinu, kondisi steady state akan sulit tercapai. Karena itu sistem operasi panen kontinu menjadi lebih sulit diadopsi. Alternatif yang menjadi pilihan operasi fotobioreaktor skala besar untuk penangkapan karbon di Indonesia adalah pemanenan sistem semi kontinyu. 
Tabel 2. Kelebihan dan kekurangan pemanenan sistem batch, semi-kontinu dan kontinu ${ }^{(28)}$

\begin{tabular}{l|l|l}
\hline \multicolumn{1}{c|}{ Sistem } & \multicolumn{1}{c}{ Kelebihan } & \multicolumn{1}{c}{ Kekurangan } \\
\hline Batch & $\begin{array}{l}\text { - Sederhana dalam konstruksi } \\
\text { - Fleksibel untuk mengganti species } \\
\text { mikroalga sewaktu-waktu } \\
\text { - Perbaikan dapat dilakukan segera }\end{array}$ & $\begin{array}{l}\text { - produksi biomassa dengan jumlah sama perlu } \\
\text { waktu lebih lama } \\
\text { kualitas dan jumlah yang dihasilkan tiap } \\
\text { panen tidak selalu sama } \\
\text { tenaga kerja untuk persiapan, pemeliharaan } \\
\text { dan panen lebih banyak. }\end{array}$ \\
\hline $\begin{array}{l}\text { Semi- } \\
\text { kontinu }\end{array}$ & $\begin{array}{l}\text { - Dapat dilakukan di dalam dan luar ruangan } \\
\text { Untuk kapasitas yang sama, produksi } \\
\text { biomassa lebih besar dibandingkan dengan } \\
\text { sistem batch }\end{array}$ & $\begin{array}{l}\text { Usia kultur tidak dapat diprediksi } \\
\text { - Peluang terkontaminasi lebih besar }\end{array}$ \\
\hline Kontinu & $\begin{array}{l}\text { Kualitas dan produksi harian lebih terjaga } \\
\text { Tenaga kerja yang diperlukan lebih sedikit } \\
\text { karena sistem otomatis, }\end{array}$ & $\begin{array}{l}\text { - Lebih kompleks } \\
\text { Biaya konstruksi lebih mahal } \\
\text { Butuh input cahaya dan suhu yang konstan, } \\
\text { sehingga sulit diaplikasikan di luar ruangan }\end{array}$ \\
\hline
\end{tabular}

\section{PERSANTUNAN}

Ucapan terima kasih penulis sampaikan kepada Pusat Teknologi Lingkungan yang telah mendukung persiapan, pelaksanaan penelitian dan sampai terwujudnya tulisan ini.

\section{DAFTAR PUSTAKA}

1. Lam, M.K., K.T. Lee, and A.R. Mohamed, (2012), Current status and challenges on microalgae-based carbon capture, Int. J. Greenhouse Gas Control, 10: 456-469.

2. Sydney, E.B., W. Sturm, J.C. de Carvalho, V. Thomaz-Soccol, C. Larroche, A. Pandey, and C.R. Soccol, (2010), Potential carbon dioxide fixation by industrially important microalgae, Biores. Technol., 101: 5892-5896.

3. Bilanovic, D., A. Andargatchew, T. Kroeger, and G. Shelef, (2009), Freshwater and marine microalgae sequestering of $\mathrm{CO}_{2}$ at different $\mathrm{C}$ and $\mathrm{N}$ concentrations - response surface methodology analysis, Energy Convers. Manage, 50: 262-267.

4. Pignolet, O., S. Jubeau, C. Vacca-Garcia, and P. Michaud, (2013), Highly valuable microalgae: biochemical and topological aspects, J. Ind. Microbiol. Biotechnol, 40: 781796.

5. de Jesus Raposo, M.F., A.M.B. de Morais, and R.M.S.C. de Morais, (2015), Marine polysaccharides from algae with potential biomedical applications, Mar. Drugs, 13: 2967-3028.

6. Hemaiswarya, S., R. Raja, R. Ravi Kumar, V. Ganesan, and C. Anbazhagan, (2011), Microalgae: a sustainable feed source for aquaculture, World. J. Microbiol. Biotechnol, 27: 1737-1746.

7. Mata, T.M., A.A. Martins, and N.S. Caetano, (2010), Microalgae for biodiesel production and other applications: A review, Renew. Sustain Energy Rev., 14: 217-232.

8. Zhao, B. and Y. Su, (2014), Process effect of microalgal-carbon dioxide fixation and biomass production: review, Renew. Sustain. Energy Rev., 31: 121-132.

9. Posten, C., (2009), Design principles of photo-bioreactors for cultivation of microalgae, Eng. Life Sci., 9: 165-177.

10. Cheah, W.Y., P.L. Show, J.S. Chang, T.C. Ling, J.C. Juan, (2015), Bioseques-tration of atmospheric $\mathrm{CO}_{2}$ and flue gas-containing $\mathrm{CO}_{2}$ by microalgae, Biores Technol., 184:190-201.

11. Raeesossadati, M.J., H. Ahmadzadeh, M.P. McHenry, and N.R. Moheimani, (2014), $\mathrm{CO}_{2}$ bioremediation by microalgae in photobioreactors: Impacts of biomass and $\mathrm{CO}_{2}$ concentrations, light, and temperature, Algal Res., 6: 78-85.

12. de Morais, M.G., and J.A.V. Costa, (2007), Carbon dioxide fixation by Chlorella kes-sleri, C. vulgaris, Scenedesmus obliquus and Spirulina sp. cultivated in flasks and vertical tubular photobioreactors, Biotechnol. Lett., 29: 1349-1352.

13. de Morais MG, JAV Costa, (2007), Biofixation of carbon dioxide by Spirulina $\mathrm{sp}$. and Scenedesmus obliquus cultivated in a threestage serial tubular photo-bioreactor, J Biotechnol., 129: 439-445

14. Chiu, S.Y., C.Y. Kao, C.H. Chen, T.C. Kuan, S.C. Ong, and C.S. Lin, (2008), Reduction of $\mathrm{CO}_{2}$ by a high-density culture of Chlorella sp. in a semicontinuous photobioreactor, Bioresour. Technol., 99: 3389-3396.

15. Huertas, E., O. Montero, and K.M. Lubian, (2000), Effects of dissolved inorganic carbon availability on growth, nutrient uptake and chlorophyll fluorescence of two species of 
marine microalgae, Aquacult. Engineer., 22: 181-197.

16. Olivieri, G., I. Gargano, R. Andreozzi, R. Marotta, A. Marzocchella, G. Pinto, and A. Pollio, (2012), Effects of $\mathrm{CO}_{2}$ and $\mathrm{pH}$ on Stichococcus bacillaris in laboratory scale photobioreactors, Chem. Eng. Trans., 27: 127-132.

17. Hulatt, C.J., and D.N. Thomas, (2011), Productivity carbon dioxide uptake and net energy return of microalgal bubble column photobioreactors, Biores Technol., 102: 5775-5787.

18. Suh, I.S. and C.G. Lee, (2003), Photobioreactor engineering: Design and performance, Biotechnol. Bioprocess Eng., 8: 313-321.

19. Widjaja, A., C.C. Chien, and Y.H. Ju, (2009), Study of increasing lipid production from fresh water microalgae Chlorella vulgaris., J. Taiwan Inst. Chem. Eng., 40: 13-20.

20. Kunjapur, A.M. and R.B. Eldridge, (2010), Photobioreactor design for commercial biofuel production from microalgae, Ind. Eng. Chem. Res., 2010: 3516-3526.

21. Jin, H.F., B.L. Ma, K. Lee, (2006), Influence of nitrate feeding on carbon dioxide fixation by microalgae, J. Environ. Sci. Health., 41: 2813-2824.

22. Ho, S.H., C.Y. Chen, and J.S. Chang, (2012), Effect of light intensity and nitrogen starvation on $\mathrm{CO}_{2}$ fixation and lipid/carbo-hydrate production of an indigenous microalga Scenedesmus obliquus CNW-N, Biores. Technol., 113: 244-252.
23. Lee, C.M., M.J. Kim, K. Sanjay, J.H. Kwag, and C.S. Ra, (2011), Biomass production potential of Chlorella vulgaris under different $\mathrm{CO}_{2}$ concentrations and light intensities, $\mathrm{J}$. Animal Sci. Technol., 53: 261-268.

24. Gonçalves, A.L., M. Simões, and J.C.M. Pires, (2014), The effect of light supply on microalgal growth, $\mathrm{CO}_{2}$ uptake and nutrient removal from wastewater, Energy Convers. Manag., 85: 530-536.

25. Pires, J. C. M., A.L. Gonçalves, F.G. Martins, M.C.M. Alvim-Ferraz and M. Simões, (2013), Effect of light supply on $\mathrm{CO}_{2}$ capture from atmosphere by Chlorella vulgaris and Pseudokirchneriella subcapitata, Mitig. Adapt. Strateg. Glob. Change., 19: 1109-1117.

26. Chae, S.R., E.J. Hwang, and H.S. Shin, (2006), Single cell protein production of Euglena gracilis and carbon dioxide fixation in an innovative photo-bioreactor, Biores. Technol., 97: 322-329.

27. Chiu, S.Y., C.Y. Kao, M.T. Tsai, S.C. Ong, C.H. Chen, and C.S. Lin, (2009), Lipid accumulation and $\mathrm{CO}_{2}$ utilization of Nannochloropsis oculata in response to $\mathrm{CO}_{2}$ aeration, Biores. Technol., 100: 833-838.

28. Coutteau, P., (1996), Microalgae, In P. Lavens and P. Sorgeloos (Eds.), Manual and The Production and Use of Live Food for Aquaculture, FAO Series Technical Paper 361, Rome, FAO., (295p.). 